\title{
An Evaluation System for Smart Growth of City
}

\author{
Wenfa Yuan \\ North China Electric Power University, Baoding 071000 \\ 812781581@qq.com
}

Keywords: Smart Growth; Index system; City development

\begin{abstract}
In order to measure the success of smart growth of a city, we built a three- level index evaluation system, which includes 1 first-level index, 4 second-level indexes and 9 third-level indexes. The first-level index called Smart Growth Index, it contains 4 second-level indexes: Economic Factors, Social Factors, Environmental Factors, Transportation Factors. They have several third-level indexes respectively, these third-level indexes cover economy, society, environment, land use, culture and traffic. Then we used analytic hierarchy process to get the weights of second-level indexes and arithmetic mean method to get the weight of third-level indexes. After the data standardization and weighted sum, we can get the score of the Smart Growth Index, and we use this to measure the success of smart growth of a city. We chose Jiayuguan in China and Geneva in Switzerland as the required two cities. And we used the Smart Growth Index's rate-of-change, which called success index, to measure the success of smart growth plans.
\end{abstract}

\section{Introduction}

With the urbanization of the world, Cities and towns all over the world are experiencing a process of history, which means that the space is expansion rapidly and the structure shape really make a huge change. Followed by these phenomena are problems, like the continuous decline of precious arable land resources, the overload of natural ecological overload and so on. By 2050, 66 percent of the world's population will be urban. Consequently, urban planning has become increasingly important.

Therefore, how to choose a reasonable strategy in the current rapid urbanization process, which will not only affect urban development of social economy and the environment, but also achieve the goal of intensive utilization of land, is particularly concerned in the world at present.

In 2000, American planning association joint 60 public bodies formed the Smart Growth America, and determined the core content of Smart Growth-- Smart growth is a kind of control of urban sprawl on the basis of improving land use efficiency, protecting the ecological environment, serving the economic development, promoting the coordinated development of urban and rural areas, and improving people life quality model of development. Smart growth focuses on building cities that embrace the E's of sustainability - Economically prosperous, socially Equitable, and Environmentally Sustainable. The most direct goal of the smart growth is to control the spread of the city. Because of the human's endless exploration, people try to establish efficient and orderly urban architecture, so as to adapt to the natural environment, and improve the human living environment.

With the development of human society, "smart growth" design concept has been more and more important in urban development. In this case, more and more communities are implementing smart growth initiatives nowadays. For example, the United States plan for the city using the theory of "smart growth", and implement these plans by the federal government, state and local governments.

\section{Model}

Defining the Metric. In this section, we derive a composite index, called the smart growth index, as the metric to measure the success of smart growth of a city.

Smart Growth Index. In order to get the smart growth index to measure the success of smart growth of a city, we build an evaluation index system. First of all, we find and read lots of articles, 
and then analyze the connotative meaning, goals and principles of "smart growth". According to the three E's of sustainability, we divide this evaluation system into four aspects: Economic Factors, Social Factors, Environmental Factors, Transportation Factors.

We select the evaluation indexes based on six of the ten principles of smart growth, including: 1) Mix land uses; 2) Take advantage of compact building design; 3) Create a range of housing opportunities and choices; 4) Create walkable neighborhoods; 5) Preserve open space, farmland, natural beauty, and critical environmental areas; 6) Provide a variety of transportation choices.

\section{Smart Growth Index via Economic Factors}

\section{The Average GDP}

The average GDP, the GDP created per square kilometers of land, shows the efficiency of land use and can partly reflect industrial and commercial intensive there. The greater the average GDP, the more advanced the economy in this region.

$$
f_{1}=\frac{G D P}{S}
$$

$G D P$ : The gross regional production in the city, million dollars

$S$ : The total area of the built up land, $\mathrm{km}^{2}$

\section{Employment Rate}

Employment rate refers to the percentage of people employed in the city.

$$
f_{2}=\frac{E P}{P_{0}} \times 100 \%
$$

$E P$ : Total number of people employed in the city

$P_{0}:$ Urban population over the age of 16

\section{Smart Growth Index via Social Factors}

\section{Urban Population Growth Elasticity Coefficient}

The ratio of urban population growth rate and the growth rate of urban land use.

$$
f_{3}=\frac{\xi p}{\xi s}
$$

$\xi p:$ Urban population growth rate, \%

$\xi_{s}:$ The growth rate of urban land use, \%

\section{The Per Capita Living Space}

The per capita living space is consisted of the per capita living area and the capita construction area.

$$
f_{9}=\frac{L S}{P}
$$

$L S:$ The total urban living space, $\mathrm{km}^{2}$

$P$ : Total number of urban population

\section{The Average Number of L\&M}

The average number of L\&M refers to the number of libraries and museums per one thousand urban people.

$$
f_{8}=\frac{L M \times 1000}{P}
$$

$L M \quad$ : Total number of libraries and museums in urban built-up areas. 


\section{Smart Growth Index via Environmental Factors}

\section{Air Quality Success Rate}

The air quality success rate refers to the percentage of the number of days when air quality reaches the standard. Air quality, judged based on pollutant concentration in the air, reflects the degree of air pollution.

$$
f_{4}=\frac{\text { days }}{365} \times 100 \%
$$

days : the number of days that air quality reaches the standard (Assuming a total of 365 days per year )

\section{Green Coverage Rate}

Green coverage refers to the vertical projection of trees, bushes, lawns and other vegetation in the city, and the green coverage rate means the percentage of green coverage in the urban built-up area.

$$
f_{5}=\frac{G C}{S} \times 100 \%
$$

GC : Urban green coverage area, $\mathrm{km}^{2}$

\section{Smart Growth Index via Transportation Factors}

\section{The Average Road Length}

The average road length refers to the length of road per one thousand urban people.

$$
f_{6}=\frac{L \times 1000}{P}
$$

\section{$L$ : Total length of urban roads, $\mathrm{km}$}

\section{The Average Number of Bus Station}

The average number of bus station refers to the number of bus station per one thousand urban people.

$$
f_{7}=\frac{B S \times 1000}{P}
$$

\section{$B S:$ The total number of bus station in the built-up area}

Determining the Weights of These Factors. Assuming that the smart growth index is a linear composition of all smart growth indicators, all we need to do is determine the weights of these factors.

We regard the smart growth index as level 1 indicator, and level 2 indicators is consisted of economic, social, environmental and transportation factors. To avoid subjective judgment, we decide to use AHP (Analytic Hierarchy Process) to determine weights of the four aspects. Besides, we apply arithmetic average weighted method to deal with the nine indicators in level3.

Obtain the Criteria Weight Vector. Determine the pairwise-comparison criteria judging matrix. Constructing the judging matrix $A=\left(a_{i j}\right)_{n^{*} n}$.

In AHP, 1-9 method are used to represent the relatively importance between criteria. 
Table 1 importance

\begin{tabular}{|c|l|}
\hline Scale & \multicolumn{1}{|c|}{ Definition } \\
\hline 1 & Indicator $i$ is equally important with indicator $j$ \\
\hline 3 & Indicator $i$ is a little more important than indicator $j$ \\
\hline 5 & Indicator $i$ is obviously more important than indicator $j$ \\
\hline 7 & Indicator $i$ is highly more important than indicator $j$ \\
\hline 9 & Indicator $i$ is extremely more important than indicator $j$ \\
\hline Reciprocal & $a_{i j}=\frac{1}{a_{j i}}$ \\
\hline
\end{tabular}

\section{Applying Consistency Checking}

Calculate the coincidence indicator CI

$$
C I=\frac{\lambda_{\max }-n}{n-1}
$$

Find the random coincidence indicator RI in the following table

Table 2 RI

\begin{tabular}{|l|l|l|l|l|l|l|l|l|l|}
\hline$n$ & 1 & 2 & 3 & 4 & 5 & 6 & 7 & 8 & 9 \\
\hline$R I$ & 0 & 0 & 0.58 & 0.90 & 1.12 & 1.24 & 1.32 & 1.41 & 1.45 \\
\hline
\end{tabular}

Calculate the consistency ratio $\mathrm{CR}$

$$
C R=\frac{C I}{R I}
$$

If the calculating ratio is less than 0.1 , then we think the judging matrix is qualified and the eigenvector with the largest eigenvalue can be used as the weight vector; If not, the judging matrix need to be modified until the less-than condition is satisfied.

\section{Analysis and Result}

- Criteria Judging matrix

$$
A=\left[\begin{array}{cccc}
1 & 1 & 2 & 3 \\
1 & 1 & 2 & 3 \\
\frac{1}{2} & \frac{1}{2} & 1 & 2 \\
\frac{1}{3} & \frac{1}{3} & \frac{1}{2} & 1
\end{array}\right]
$$

- the maximum eigenvalue $\lambda_{\max }=4.0104$, and the corresponding criteria vector is $x=\left(x_{1}, x_{2}, x_{3}, x_{4}\right)^{T}=(-0.6473,-0.6473,-0.3487,-0.2013)^{T}$

The final score of four alternatives are: 
Table 3 Score

\begin{tabular}{|c|c|c|}
\hline Rank & Index & Score \\
\hline 1 & Economic Factors & 0.351 \\
\hline 2 & Social Factors & 0.351 \\
\hline 3 & Environmental Factors & 0.189 \\
\hline 4 & Transportation Factors & 0.109 \\
\hline
\end{tabular}

The result of AHP shows that Economic Factors and Social Factors play significant roles in evaluating the success of smart growth of a city. Followed by Environmental Factors and transportation Factors get the highest score in the evaluation process.

In the process of consistency checking, $\quad C I=3.467 \times 10^{3}$ and the consistency ratio $C R=3.85 \times 10^{-3}<0.1$. Therefore, we think the judging matrix is qualified and the eigenvector with the largest eigenvalue can be used as the weight vector.

\section{The Final Score of all Indicators}

Table 4. Final Score

\begin{tabular}{|c|c|c|c|c|c|}
\hline $\begin{array}{l}\text { Level } 1 \\
\text { Indicators }\end{array}$ & $\begin{array}{l}\text { Level } 2 \\
\text { Indicators }\end{array}$ & Weight & Level 3 Indicators & Weight & $\begin{array}{c}\text { Total } \\
\text { Weight }\end{array}$ \\
\hline \multirow{9}{*}{$\begin{array}{l}\text { Smart } \\
\text { Growth } \\
\text { Index }\end{array}$} & \multirow{2}{*}{$\begin{array}{l}\text { Economic } \\
\text { Factors }\end{array}$} & \multirow{2}{*}{0.351} & The Average GDP & 0.5 & 0.1755 \\
\hline & & & Employment Rate & 0.5 & 0.1755 \\
\hline & \multirow{3}{*}{ Social Factors } & \multirow{3}{*}{0.351} & $\begin{array}{c}\text { Urban Population } \\
\text { Growth Elasticity } \\
\text { Coefficient }\end{array}$ & $1 / 3$ & 0.117 \\
\hline & & & $\begin{array}{l}\text { The Per Capita } \\
\text { Living Space }\end{array}$ & $1 / 3$ & 0.117 \\
\hline & & & $\begin{array}{c}\text { The Average Number } \\
\text { of L\&M }\end{array}$ & $1 / 3$ & 0.117 \\
\hline & \multirow{2}{*}{$\begin{array}{c}\text { Environmental } \\
\text { Factors }\end{array}$} & \multirow{2}{*}{0.189} & $\begin{array}{c}\text { Air Quality Success } \\
\text { Rate }\end{array}$ & 0.5 & 0.0945 \\
\hline & & & Green Coverage Rate & 0.5 & 0.0945 \\
\hline & \multirow{2}{*}{$\begin{array}{c}\text { Transportation } \\
\text { Factors }\end{array}$} & \multirow{2}{*}{0.109} & $\begin{array}{c}\text { The Average Road } \\
\text { Length }\end{array}$ & 0.5 & 0.0545 \\
\hline & & & $\begin{array}{c}\text { The Average Number } \\
\text { of Bus Station }\end{array}$ & 0.5 & 0.0545 \\
\hline
\end{tabular}

\section{Analyzing the Growth Plans of Two Mid-Sized Cities}

In this section, we select Jiayuguan City and Geneva City, two mid-sized cities (any city with a population of between 100,000 and 500,000 persons).

\section{Jiayuguan City}

\section{The Current growth plan.}

- Target Time : 2030

- The guiding ideology:

Regard the scientific outlook on development as the guide, fully rely on jiayuguan's historical cultural resources, protect the heritages of historic culture, and improve the quality of the city comprehensively.

- Development goals:

1) The population of jiayuguan city region should be controlled within 570000; 
2) The green coverage rate should be more than $35 \%$;

3) The scale of construction land should be controlled within 80 square kilometers;

4) GDP in Jiayuguan should reach 280 billion yuan.

\section{Geneva City}

\section{The Current Growth Plan.}

The planning directions:

1) To promote social fairness, eliminate gender, racial discrimination;

2) To promote the local economic development, local economic diversification, strengthen creative

3) To develop social policy, increase the housing area, reduce the burden of the people's housing.

The measures:

1) The division and protection of historical building area;

2) The construction of urban green belts;

3) The optimization reconstruction of community to satisfy the demand of the public

\section{Evaluate}

Find data and put them into our evaluation system, then we can get success index, blow is the result:

Table 5. Result

\begin{tabular}{|c|c|c|c|c|c|c|}
\hline \multirow{3}{*}{$\begin{array}{l}\text { city } \\
\text { factors }\end{array}$} & \multicolumn{4}{|c|}{ Initial Data } & \multicolumn{2}{|c|}{ Success } \\
\hline & \multicolumn{2}{|c|}{ Jiayuguan } & \multicolumn{2}{|c|}{ Geneva } & \multirow{2}{*}{$\begin{array}{l}\text { Jiayug } \\
\text { uan }\end{array}$} & \multirow{2}{*}{$\begin{array}{l}\text { Genev } \\
\text { a }\end{array}$} \\
\hline & 2015 & 2030 & 2015 & 2050 & & \\
\hline The Average GDP & $\begin{array}{c}50.661 \\
3\end{array}$ & $\begin{array}{c}514.70 \\
588\end{array}$ & $\begin{array}{c}889.1 \\
738\end{array}$ & $\begin{array}{c}1078 . \\
947\end{array}$ & \multirow{9}{*}{$\begin{array}{c}-0.111 \\
53\end{array}$} & \multirow{9}{*}{$\begin{array}{c}9.2803 \\
35\end{array}$} \\
\hline Employment Rate & $\begin{array}{c}0.7409 \\
07\end{array}$ & 0.75 & 73.13 & 75 & & \\
\hline $\begin{array}{l}\text { Urban Population Growth } \\
\text { Elasticity Coefficient }\end{array}$ & $\begin{array}{c}0.5289 \\
18\end{array}$ & $\begin{array}{c}6.7651 \\
899\end{array}$ & $\begin{array}{c}1.279 \\
786\end{array}$ & $\begin{array}{c}1.072 \\
933\end{array}$ & & \\
\hline The Per Capita Living Space & 37.94 & $\begin{array}{c}33.622 \\
364\end{array}$ & 36.76 & $\begin{array}{c}46.38 \\
834\end{array}$ & & \\
\hline The Average Number of L\&M & $\begin{array}{c}0.0219 \\
39\end{array}$ & $\begin{array}{c}0.0090 \\
909\end{array}$ & $\begin{array}{c}0.200 \\
447\end{array}$ & $\begin{array}{c}0.176 \\
717\end{array}$ & & \\
\hline Air Quality Success Rate & 0.9 & 0.9 & $\begin{array}{c}0.863 \\
014\end{array}$ & $\begin{array}{c}0.876 \\
712\end{array}$ & & \\
\hline Green Coverage Rate & $\begin{array}{c}0.3972 \\
86\end{array}$ & 0.4 & 0.434 & 0.45 & & \\
\hline The Average Road Length & $\begin{array}{l}4.2913 \\
56\end{array}$ & $\begin{array}{c}1.7781 \\
818\end{array}$ & $\begin{array}{c}2.528 \\
718\end{array}$ & $\begin{array}{c}2.429 \\
865\end{array}$ & & \\
\hline $\begin{array}{l}\text { The Average Number of Bus } \\
\text { Station }\end{array}$ & $\begin{array}{c}0.7985 \\
96\end{array}$ & $\begin{array}{c}0.3309 \\
091\end{array}$ & $\begin{array}{c}0.801 \\
789\end{array}$ & $\begin{array}{c}0.684 \\
78\end{array}$ & & \\
\hline
\end{tabular}

From the table we can find that the plan from Jiayuguan government is somehow not fully in accordance with ten principles of smart growth and development of Geneva is very appropriate for smart growth.

\section{Reference}

[1] J. van der Geer, J.A.J. Hanraads, R.A. Lupton, The art of writing a scientific article, J. Sci. 
Commun. 163 (2000) 51-59.

[2] W. Strunk Jr., E.B. White, The Elements of Style, third ed., Macmillan, New York, 1979. Reference to a chapter in an edited book:

[3] G.R. Mettam, How to prepare an electronic version of your article, in: B.S. Jones, R.Z. Smith (Eds.), Introduction to the Electronic Age, E-Publishing Inc., New York, 1999, pp. 281-304.

[4] R.J. Ong, J.T. Dawley and P.G. Clem: submitted to Journal of Materials Research (2003)

[5] P.G. Clem, M. Rodriguez, J.A. Voigt and C.S. Ashley, U.S. Patent 6,231,666. (2001) 